\title{
Drug induced liver damage in a universitary hospital
}

\author{
Lesão hepática induzida por drogas em um hospital universitário
}

\author{
Mariana Porto Magalhães ${ }^{1}$, Raymundo Paraná2, Genário Oliveira Santos Júnior ${ }^{3}$, Caio Gomes dos Santos \\ Araújo ${ }^{4}$, Vinicius Santos Nunes ${ }^{5}$, Maria Isabel Schinoni ${ }^{6 *}$ \\ ${ }^{1}$ Graduada em Medicina pela Universidade Federal da Bahia - UFBA; ${ }^{2}$ Professor titular e Livre Docente da \\ Faculdade de Medicina da UFBA; ${ }^{3}$ Farmacêutico do HUPES. Mestre em saúde UFBA; \\ ${ }^{4}$ Acadêmico de Medicina; ${ }^{5}$ Médico Gastroenterologista do Serviço de Gastrohepatologia do HUPES UFBA; \\ ${ }^{6}$ Doutora em Medicina e Saúde pela UFBA. Professor Permanente da Pós Graduação em Processos Interativos de Órgãos e \\ Sistema da Universidade Federal Bahia/Instituto de Ciências da Saúde
}

\begin{abstract}
Resumo
Introdução: lesão hepática induzida por drogas (DILI) é responsável por um amplo espectro de lesão hepática. Clinicamente, esses eventos são apresentados de várias formas e, para alcançar um diagnóstico diferente, outras causas de lesões devem ser excluídas. Objetivo: identificar e caracterizar casos de hepatotoxicidade induzida por medicamentos, fitoterápicos e suplementos alimentares em Hospital Universitário no Brasil. Metodologia: estudo observacional, retrospectivo. Os dados foram coletados em prontuários do Hospital Universitário, entre agosto de 2009, em agosto de 2014. A causalidade das reações medicamentosas suspeitas foi avaliada pelo Conselho de Organizações Internacionais de Ciências Médicas (CIOMS). Resultados: foram selecionados 30 casos suspeitos, $50 \%$ do sexo feminino e média de 39 anos. As classes terapêuticas mais comuns foram: anti-infecciosos; agentes antineoplásicos; drogas do sistema nervoso central, esteroides anabolizantes e suplementos herbáceos e dietéticos (HDS). Lesão colestática ou mista foi observada em $73 \%$ desses casos; $60 \%$ eram altamente prováveis, de acordo com o CIOMS. Conclusão: DILI é causada por uma grande variedade de drogas, suplementos dietéticos e suplementos dietéticos. Anti-infecciosos e quimioterapia foram responsáveis por grande parte da resposta.
\end{abstract}

Palavras-chave: Suplementos dietéticos. Hepatite tóxica. Lesão Hepática Induzida por Drogas.

\begin{abstract}
Background: drug Induced Liver Injury (DILI) is responsible for wide spectrum of liver injury. Clinically, these events are presented in various forms and for reaching a different diagnosis other injury causes must be excluded. Aim: identify and characterize cases of hepatotoxicity induced by drugs, herbal and dietary supplements in University Hospital in Brazil. Methodology: observational and retrospective study. Was collected in records of University Hospital, between August 2009 at August 2014. The causality of the drug reactions suspected were evaluated Council for International Organizations of Medical Sciences (CIOMS). Results: we selected 30 suspected cases, $50 \%$ was female and average was 39 years. the therapeutic classes most common was: anti-infectives; antineoplastic agents; central nervous system drugs, anabolic steroid and herbal and dietary supplements (HDS). Cholestatic or mixed injury was observed in $73 \%$ these cases; $60 \%$ were highly probable, according to CIOMS. Conclusion: DILI is caused by a wide variety of drugs, dietary supplements and dietary supplements. Anti-infectives and chemotherapy were responsible for much of the response.

Keywords: Herbal and dietary supplements. Toxic Hepatitis. Drug-Induced Liver Injury.
\end{abstract}

\section{INTRODUCTION}

Drug induced liver injury (DILI) is a great problem of public health. It is the first cause of acute liver failure, being responsible for a broad spectrum of liver diseases. It is a challenge to pharmaceutical industry, requiring studies with a big number of patients to study the drug safety?

Hepatotoxicity may be caused by a direct liver injury or a dysfunction developing cellular lesion. Peroxidation of lipids in hepatocytes membrane by free radicals or intermediary metabolites is an example of direct mechanism. Other mechanisms are covalent bound with intracellular

Correspondente/Corresponding: *Maria Isabel Schinoni - Hospital Universitário Prof. Edgard Santos. Rua Augusto Viana, S/N, Canela, Salvador, Bahia, Brasil. CEP: 40.110-060. - Tel: (71) 3283-8395/99995359 - E-mail: mariaschinoni4@gmail.com proteins, apoptosis activation, mitochondrial inhibition and interference with proteins involved in biliary salt exportation, or immunologic mechanisms, with the destruction of hepatocytes by a cytokine Tumor Necrosis Factor: TNF and/or Fas ${ }^{3}$.

Herbal and Dietary supplement (HDS) were responsible for $43 \%$ of the DILI cases in some studies 4 . In a reference center in USA, drug induced hepatotoxicity was cause for 32 of 96 (33\%) fulminant hepatitis cases ${ }^{5}$. Another study, on Massachusetts general population, showed a 40,6/100.000 persons for year incidence of hepatotoxicity causing liver enzymes anormality ${ }^{6}$.

According to World Health Organization (WHO) more than 3 million cases of drug induced liver injury were notified since $1968^{7,8}$. The most frequent drugs related 
were: acetaminophen (17\%), antiretroviral therapy (17\%), chemotherapy, including flutamide, cyclophosphamide, methotrexate, methotrexate and cytarabine, (12\%), anticonvulsants (10\%), antibiotics (9\%), diclofenac (9\%), anesthetic agents (5\%), antitubercular agents (3\%). The aim of this study was identify and characterize cases of hepatotoxicity induced by drugs, herbal and dietary supplements in an University Hospital in Brazil.

\section{METHODOLOGY}

It was observational and retrospective study, the cases were related from outpatients from Complexo Hospitalar Universitário Professor Edgard Santos (C-HUPES) in Salvador, Bahia, Brazil. These were collected from patients records, a specifically questionnaire was filled. The variables used were: age, sex, drug compound suspected of hepatic injury, use of concomitant medication, outcome (time of resolution, complications, treatment), biochemical, imaging and biopsy data, if available.

The inclusion criteria of the study were: all the cases that were reported from the Hospital to Pharmacovigilance Center or cases that were reported from Gastroenterology outpatients clinic of the hospital admitted between August 2009 and August 2014. The exclusion criteria were: all the cases with lack of information on time of hepatic injury being not possible to identify the drug lesion causality.

The biochemical criteria that characterized DILI were: alanine transaminase $(A L T) \geq 5 x$ higher than the normal limit ( $x U L N)$; alkaline phosphatase $(A L P) \geq 2 \times U L N$ or ALT $\geq 3 \times \cup L N+$ bilirubin $(T B) \geq 2 x \cup L N$. The type of liver injury was classified according to $R$ values (ALT/ULN)/(ALP/ULN), which were calculated from the blood tests results after $D I L I$ suspicion. The $R$ ratio determines whether the injury is hepatocellular $(R>5)$, cholestatic $(R<2,0)$, or mixed $(R=2,0-5,0)^{9}$.

The patients who had suspected drug-induced liver injury were required to perform viral serology (HAV, HBV, $H C V, C M V, E B V$ ) and autoantibodies (FAN, Anti-LKM, AML) test and abdominal ultrasound in order to discard other liver diseases.

The CIOMS (Council for International Organizations of Medical Sciences) scale was applied to all cases that were diagnosed as $D_{I L I}{ }^{10}$. Statistical analyses were descriptive. The Ethics Committee Board of Professor Edgard Santos University Hospital (Salvador, Bahia, Brazil) approved the study. All subjects gave informed written consent to participate in the study.

The statistical analysis was descriptive. The numbers were organized and later tabulated with the help of Microsoft Office Excel 2013 software, which produced spreadsheets with the results, with subsequent presentation in the form of graphs and tables. Frequency was utilized to show the most frequent drug involved in DILI

\section{RESULTS}

From august 2009 to September 2014, 30 patients were included, 50\% (16/30) were female, mean age of 39 years; $77 \%(23 / 30)$ individuals were afrodescendant. Of total of patients $30,23 \%(7 / 30)$ presented at least one of the following symptoms: abdominal pain, jaundice, choluria or pruritus. There were no patients with fever, arthralgia, rash or eosinophilia. Only one patient with previous cirrhosis developed hepatic encephalopathy.

The $R$ value was calculated from the lab values results on the day of DILI recognition. Cholestatic or mixed injury pattern were present in $73 \%$ of patients and $27 \%$ (8/30) had hepatocellular pattern injury.

DILI was caused by allopathic medicine in $90 \%$ (27/30), by HDS in 6\% (2/30) and $4 \%(1 / 30)$ recreational drug. The most implicated drugs were: antituberculostatics $23 \%(7 / 30)$, anti infection $17 \%$ (5/30), antineoplastic $14 \%$ (4/30). Non-steroidal anti-inflammatory drugs 6\% (2/30), oral contraceptive 6\% (2/30) and immunosuppressant 6\% (2/30) (Figure 1).

Figure 1 - Frequency of drugs causing DILI cases in Universitary Hospital of 2009 at 2012.

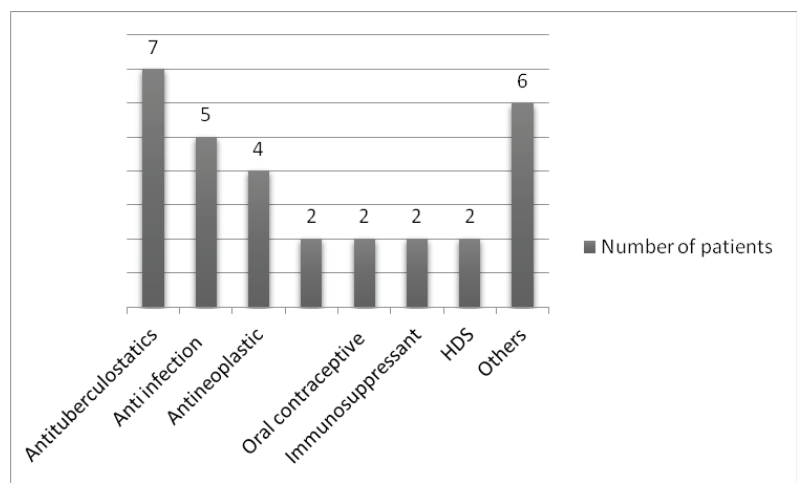

Source: own authorship

The allopathic medicine most frequent was isoniazid, HDS and recreational drug found were an infusion tea "mãe boa" - Ruellia baiensis, RIP CUTZ ${ }^{\circledR}$ (3 2-c pyrazole - 5alpha - etioallocholane-17b-tetrahydropyranol 16,6mg, 2a, 17a dimethyl-etiocholan-3-one, 17b-ol 10mg e 2a, 3a epithio17a-methyl-17b-hydroxy-5a-androstran 5mg) - anabolic steroid; and "crazy princess"-. a Berber mix of brandy, sugarcane liquor, vodka, Erythroxylum catuaba, honey, Paullinia cupana, Zingiber officinale and Allium sativum.

Complete remission was observed in $70 \%(21 / 30)$ of the cases after suspended the related drug, 27\% (8/30) needed treatment and in $3 \%$ of $(1 / 30)$ cases had liver transplant. None patient performed rechallenge. All the patients had complete recuperation None of patients developed chronic DILI, and 1 patient progressed to acute liver failure.

By using the CIOMS for drug causality assessment, 60 $\%(18 / 30)$ were classified as highly probable, $27 \%(8 / 30)$ as probable and $23 \%(5 / 30)$ were as possible. 


\section{DISCUSSION}

DILI is one of the most common type of liver disease in hepatology. In this study $51 \%$ of the patients were female, and the average was 38 years (20 to 64 years. This data was similar with the previous literature related, such as Andrade et al., in a multicentric study from Spain (461 patients in a 10 year period). Sgro et al., in a 34 cases study with french population ${ }^{15}$ and Chalasani ${ }^{11}$, who studied 300 patients in United States ${ }^{11}$, founded the same results.

The anti-infections drugs as (isoniazid, voriconazole, amphotericin, abacavir, nevirapin, meglumine antimoniate and ciprofloxacin) share the majority of reactions, $41 \%$ of cases. Antineoplasic agents (melphalan, etoposide, dasatinibe, cyclosporine e imatinibe) were second culprit drug most common in these cases. Chalasani et al., stated that in 217 patients who had only one drug involved in the hepatic injury, the most therapeutic class was anti-infectives and central nervous system drugs ${ }^{11}$. In Spain, in a 10-years of DILI registry, the main pharmacological groups were anti-infectives drugs, central nervous system and non-steroidal anti-inflammatory drugs ${ }^{12}$.

The anabolic steroid and homemade infusions was observed too. In Iceland 16\% of the DILI, was associated with herbal supplies. In recent Spanish Study, DILI was related in 2,3\% of the patients using Anabolic Steroids drugs, we found similar data in this study ${ }^{13}$. According to Andrade et al, DILIN secondary to anabolic steroid drug had increased reports from $7 \%$ to $20 \%$ between 2004 at $2013^{12}$. In this study $3 \%$ of the reported cases was HDS. The herbal medicines implicated with the liver damage were Ruellia baiensis, Erythroxylum catuaba, Paullinia cupana, Zingiber officinale and Allium sativum. In this herbal species, was reported DILI with Paullinia cupana, one case and Paullinia cupana, two cases, the others species weren't report in literature ${ }^{14,15}$.

In a series of 34 DILI cases, Sgro et al. found 10\% of non-steroidal anti-inflammatory drugs ${ }^{16}$, and in the Spanish registry was related, along 10 -years, $11 \%$ of DILI cases was non-steroidal anti-inflammatory drugs. The frequency this drug in our studied population was less when, only $6 \%$, but our patient sample was smaller when compared that Spanish Group ${ }^{12}$.

In this study, $72 \%$ of DILI had cholestatic or mixed injury pattern. Sgro et al. and Chalasani et al. also showed difference in frequency between fenotipe of liver injury ${ }_{11,16}$. However, among patients who had acute liver failure, Chalasani et al. found $82 \%$ of the lesions with hepatocellular injury, data corroborated by Reuben et al., where $71 \%$ of acute hepatic failure by DILI were with hepatocellular pattern ${ }^{11,17}$. The only case that occurred with acute liver failure, probably secondary to use herbal medicine, Ruellia baiensis, also had hepatocellular damage.

In this series, isoniazid was the substance that appeared most frequently involved in the etiology of the hepatic injury. Andrade et al. and Chalasani et al. found amoxicillin - clavulanate as the most common individual agent in the causes of DILI ${ }^{11,12}$. In our study there were no registered cases.

In relation to severity one only patient had acute liver failure, and recovered with liver transplant.

Application of CIOMS/RUCAM scale produced as highly probable in $60 \%$ of these cases in the study. In others studies, RUCAM scale showed as probable in the majority of the studies ${ }^{13}$.

\section{CONCLUSION}

This is the first DILI cases reported in our hospital population. In this study anti-infective drugs and chemotherapy drugs were responsible for the most of hepatic injury. Hepatocelular damage was the most common phenotype of DILI in this sample and the most of patients had completely recuperation.

\section{REFERENCES}

1. BITTENCOURT, P. Epidemiologia da hepatotoxicidade por drogas. In: Reunião com Expertos em Hepatotoxicidade da Sociedade Brasileira de Hepatologia: analgésicos, antitérmicos, insumos vegetais, fitoterápicos, homeopáticos e AINEs. GED Gastroenterol. Endosc. Dig., São Paulo, v. 30, n. 1, p. 14-16, 2011.

2. DUH, M. S.; WALKER; A. M.; KRONLUND JUNIOR, K. H. Descriptive epidemiology of acute liver enzyme abnormalities in the general population of central Massachusetts. Pharmacoepidemiol. Drug Saf., Chichester, v. 8, n. 4, p. 275-283,1999.

3. BERTOMLAMI, M. C. Mechanisms of hepatotoxicity. Arq. Bras. Cardiol., São Paulo, v. 85, n. 5, p. 25-27, 2005.

4. VEGA, M. et al. The Incidence of Drug - and Herbal and Dietary Supplement-Induced Liver Injury: Preliminary Findings from Gastroenterologist-Based Surveillance in the Population of the State of Delaware. Drug Saf., Auckland, v. 40, n. 9, p. 783-787, 2017.

5. PARANÁ, R.; WASKMAN, J. C. Mecanismos de hepatotoxicidade medicamentosa: o exemplo do acetaminofen/paracetamol. In: Reunião com Expertos em Hepatotoxicidade da Sociedade Brasileira de Hepatologia: analgésicos, antitérmicos, insumos vegetais, fitoterápicos, homeopáticos e AINEs. GED Gastroenterol. Endosc. Dig., São Paulo, v. 30, n. 1, p. $10-13,2011$.

6. TAJIRI, K.; SHIMIZU, Y. Practical guidelines for the diagnosis and early management of drug-induced liver injury. World J. Gastroenterol., Beijing, v. 14, n. 44, p. 6774-6785, 2008.

7. U.S. National Library of Medicine. Causality. Bethesda. Disponível em: < https://livertox.nih.gov>. Acesso em: 15 apr. 2016.

8. U.S. National Library of Medicine. Glossary. Bethesda. Disponivel em: < https://livertox.nih.gov/>. Acesso em: 15 apr. 2016.

9. AITHAL, G. P. et al. Case definition and phenotype standardization in drug-induced liver injury. Clin. Pharmacol. Ther., St. Louis, v. 89, n. 6, p. 806-815, 2011.

10. BENICHOU, C. 1.; DANAN, G.; FLAHAULT, A. Causality assessment of adverse reactions to drugs--II. An original model for validation of drug causality assessment methods: case reports with positive rechallenge. J. Clin. Epidemiol., Oxford, v. 46, n. 11, p. 1331-1336, 1993.

11. CHALASANI, N. et al. Causes, Clinical Features, and Outcomes From a Prospective Study os Drug-Induced Liver Injury in the United States. Gastroenterology, Baltimore, v. 135, n. 6, p. 1924-1934e4, 2008. 
12. ANDRADE, R. J. et al. Drug-Induced liver injury: na analysis of 461 incidences submitted to the spanish registry over a 10-year period. Gastroenterology, Baltimore, v. 129, n. 2, p. 512-521, 2005.

13. MEDINA-CALIZ, I. et al. Herbal and dietary supplement-induced liver injuries in the spanish dili registry. Clin. Gastroenterol. Hepatol., Philadelphia, v. 16, n. 9, p. 1495-1502, 2018.

14. SCHOEPFER, A. M. 1. et al. Herbal does not mean innocuous: ten cases of severe hepatotoxicity associated with dietary supplements from Herbalife products. J. Hepatol., Amsterdam, v. 47, n. 4, p. 521-526, 2007.
15. TESCHKE, R. 1. et al. Herbal hepatotoxicity: a tabular compilation of reported cases. Liver Int., Oxford, v. 32, n. 10, p. 1543-1556, 2012.

16. SGRO, C. et al. Incidence of Drug-Induced Hepatic Injuries: A French Papulation-Based Study. Hepatology, Baltimore, v. 36, n. 2, p. 451-455, 2002.

17. REUBEN, A.; KOCH, D. G.; LEE, W. M. Drug-induced acute liver failure: results of a U.S. multicenter, prospective study. Hepatology, Baltimore, v. 52, n. 6, p. 2065-2076, 2010.

Submetido em: 24/02/2019

Aceito em: 07/07/2019 